\title{
Zero Energy Hotels and Sustainable Mobility in the Islands of Aegean Sea (Greece)
}

\author{
Giuseppe Maria Perfetto, Francesco Paolo Lamacchia \\ Network Ec0-Edifici a Consumo Zero, Matera, Italy \\ Email:jperfetto@solardesign.it,lamacchiafp@yahoo.it
}

Received 10 December 2015; accepted 2 May 2016; published 5 May 2016

Copyright (C) 2016 by authors and Scientific Research Publishing Inc.

This work is licensed under the Creative Commons Attribution International License (CC BY).

http://creativecommons.org/licenses/by/4.0/

(c) (i) Open Access

\section{Abstract}

The goal of this work is to evaluate and to give evidence to innovative and sustainable technologies applied in the construction industry to carry out self-sufficient energy and to use the surplus energy for the production of hydrogen vector. An architectural integration design along with high technological systems is performed. The intermittency of renewable energy sources along with climatic conditions dependency imposes to store the energy produced, since it is clean and having a big calorific value: the hydrogen vector is currently the better energy carrier. The energy to obtain hydrogen by dissociation of water is supplied by a photovoltaic (PV) system. Through the computations of the annual energy balance between building's demand and supply energy, it is shown that the extra energy produced by the solar generation system is used also for the hydrogen sustainable mobility. The renewable systems, model's design and case study are tackled for the bigger one of the Dodecanese islands in the South Aegean Sea: Rhodes (Rodos). The Zero energy building's integrative design-based approach, applied to the Hotel Buildings type industry is targeted to have new hotels buildings, in the Mediterranean typical warm climate, with zero energy consumption. The designers, authors of this work, have studied a real case or pilot project of an hotel, in the resort formula, suitable to the Greek landscape, showcasing technologies and innovations supporting environmental sustainability, energy efficiency, use of renewable energy, electricity storage by fuel cells that are tools particularly applicable to hotel facility [1]. The feasibility of this case study or pilot project is aligned jointly to the target of Zero Emission and Energy Efficiency EU Policy, as imposed by EU Directives. The strategic position of Rhodes in a geographical point full of sun and wind renewable energy power, enables to ensure the clean energy production, the current interesting development of the hydrogen as energy vector in the buildings [2] and also to satisfy the demand of tourists' accommodation by having at the same time zero energy costs. Moreover, the presence in the island of the best example worldwide of ancient and sustainable built environment (UNESCO World Heritage site), represents also the best motivation to give witness there of a zero impact environmental urban development through the adoption of these achieved scientific results for a major success of Zero Energy Buildings. 


\section{Keywords}

\section{Zero Energy Buildings, ZEB, nZEB Design, Zero Energy Cities, nZEH, Hydrogen, Sustainable Building, ZEH, Sustainable Mobility}

\section{Introduction}

The island of Rhodes (Greece) is located at the crossroads of two major sea routes of the Mediterranean between the Aegean Sea and the coast of the Middle East, as well as Cyprus and Egypt. Its position in southeastern Greece allows to the island to have the longest summer of any of the Greek Islands and a tourist season that starts before April and ends sometime in November.

The insertion of the project is on the island of Rhodes as an exemplary place in the Mediterranean basin due to one of its peculiarities like a very touristic location, and consequently with high need of accommodation buildings, and with high renewable energy sources potentiality.

The project can be replicated in similar climatic areas using the same design concepts, but each time, adapting materials and indigenous building techniques (Figure 1).

The characteristics of the place make the landscape a significant challenge for the characteristics of the climate [3].

An assessment of the requirements of a sustainable building has made a preliminary study on bioclimatic analysis; solar control; induced natural ventilation; the energy contribution of passive systems for heating, ventilation and cooling with geothermal support [4] (Figure 2, Table 1).

To do this, it is important to know the context of the climate.

The climate data indicate a great availability of solar radiation but also the need to be strongly air-conditioned environments during the spring/summer (Figure 3, Table 2).

\section{Bioclimatic Architecture \& Active Solar Systems: A Multi-Functional Envelope That Takes into Account Summer Comfort}

The envelope becomes multi-functional: It allows both to protect from the outside environment, but also to draw its energy (from the sun, the outdoor air, the soil, the wind...). Thermal mass and insulation, solar protection, ventilation, day lighting are thus associated; a well-designed envelope can avoid or remove the use of traditional installations of heating or air-conditioning.

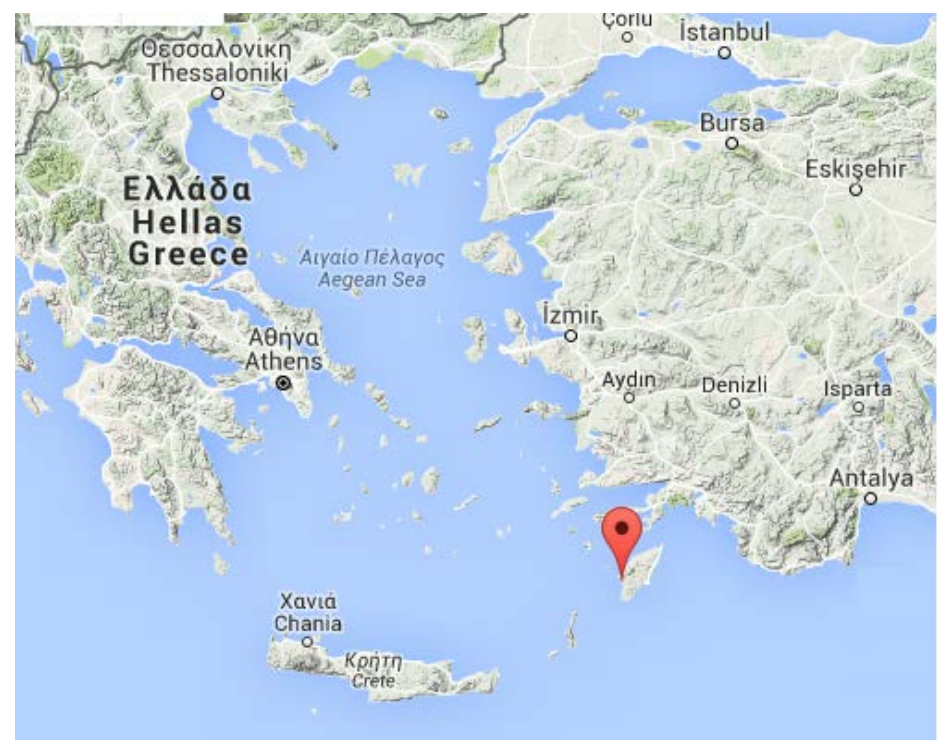

Figure 1. Project location. 


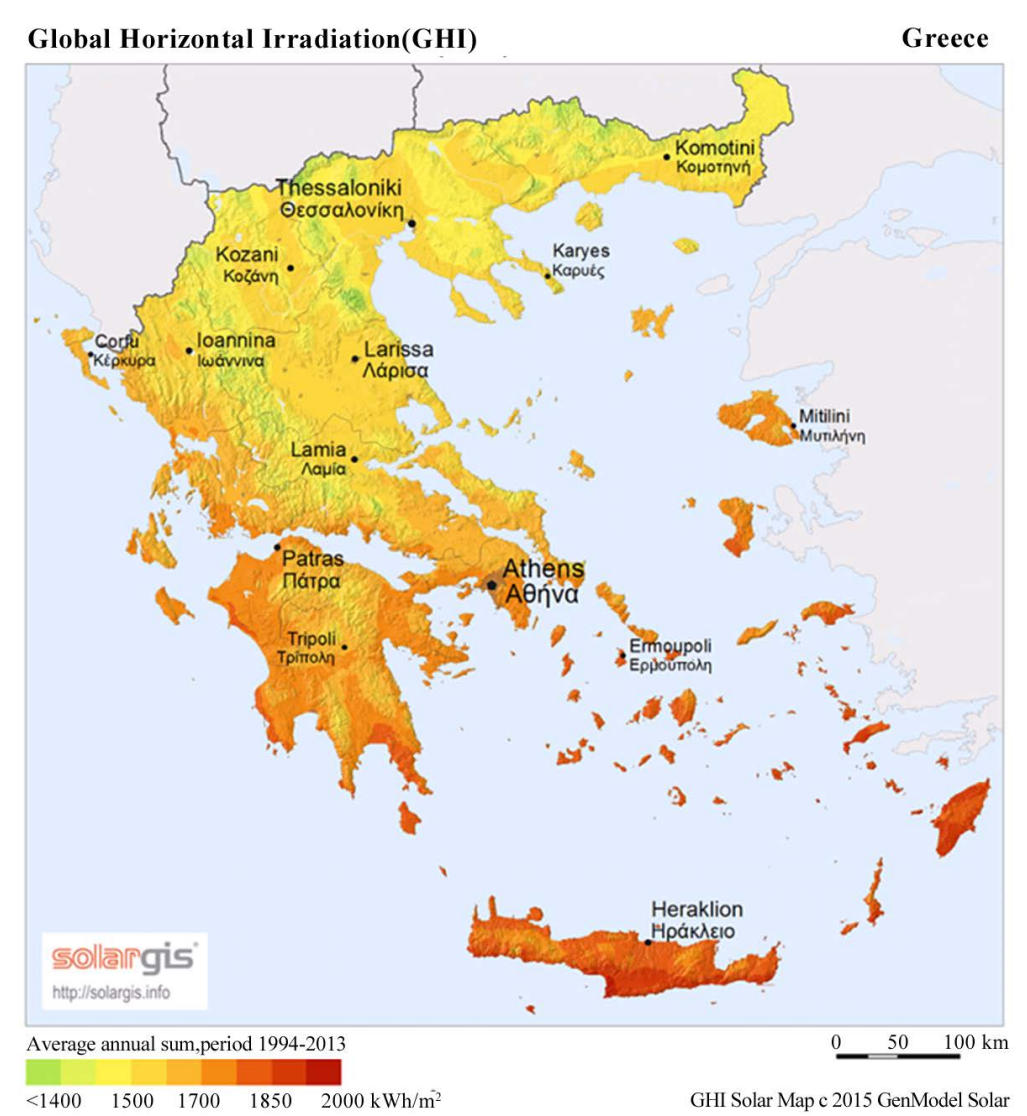

Figure 2. Area's global horizontal irradiation.

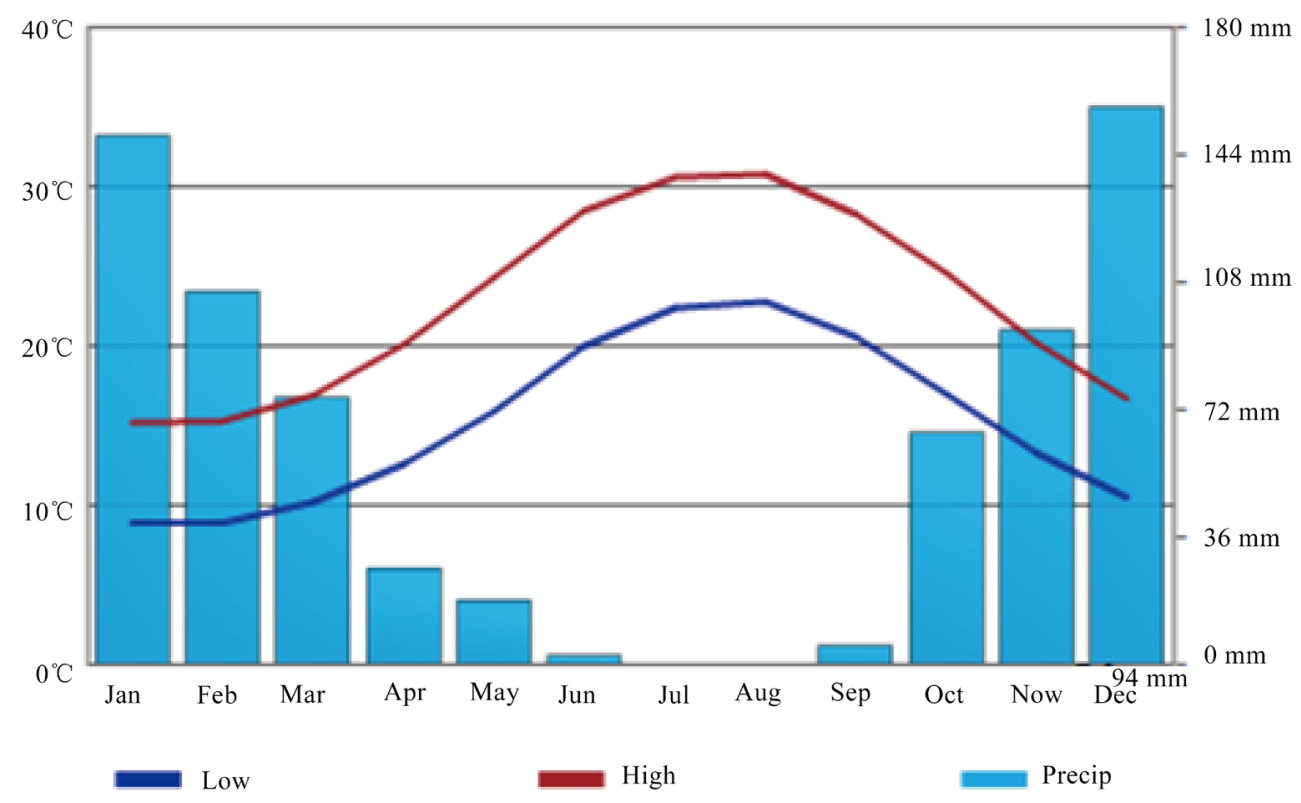

Figure 3. Rhodes climate data.

Being a hot-arid climate is fundamental the proper use of the thermal mass, which is the property of heavy materials to retain long heat or cold and release it over time; this technique also allows to slow down the thermal lag between the external temperature and the internal one. 
Table 1. Rhodes climate data.

\begin{tabular}{cccccccccccccc}
\hline & \multicolumn{10}{c}{ Climate Rhodes-Greece } \\
\hline Temperature ${ }^{\circ} \mathrm{C}$ & Jan & Feb & Mar & Apr & May & June & July & Aug & Sep & Oct & Nov & Dec \\
\hline Average high in ${ }^{\circ} \mathrm{C}$ & 15 & 15 & 17 & 20 & 24 & 28 & 31 & 31 & 28 & 25 & 20 & 17 \\
Average low in ${ }^{\circ} \mathrm{C}$ & 9 & 9 & 10 & 13 & 16 & 20 & 22 & 23 & 21 & 17 & 13 & 10 \\
Av. precipitation-mm & 149 & 105 & 75 & 27 & 18 & 2 & 0 & 0 & 5 & 65 & 94 & 157 \\
Days with precip. & 15 & 12 & 10 & 7 & 4 & 1 & 0 & 0 & 1 & 6 & 9 & 15 \\
Hours of sunshine & 139 & 151 & 210 & 261 & 313 & 348 & 387 & 378 & 321 & 244 & 189 & 136 \\
\hline
\end{tabular}

Climate chart Rhodes-south Aegean.

Table 2. Synthesis of climate data.

\begin{tabular}{cc}
\hline Climate Greece & \\
\hline Totals and averages & $22.5^{\circ} \mathrm{C}$ \\
\hline Annual average high temperature: & $15.2^{\circ} \mathrm{C}$ \\
Annual average low temperature: & $18.8^{\circ} \mathrm{C}$ \\
Average temperature: & $697 \mathrm{~mm}$ \\
Average annual precipitation: & $80 \mathrm{~d}$. \\
Days per year with precipitation: & $3077 \mathrm{~h}$. \\
\hline
\end{tabular}

Microclimate and project: taking into account the local climate and site context, specific cooling strategies can be selected to apply that are most appropriate to prevent overheating through the building envelope. The microclimate can play a huge role in determining the location of the building more favorable analysis of the combined availability of sun and wind. The graph bioclimatic, solar chart and the compass are important design tools in the application of this technique.

Solar control: to contribute effectively to minimize solar heat gains are calculated a correct shading system [5]. Shadow is transparent and opaque surfaces of the building will minimize the amount of solar radiation that causes overheating in both the interiors and the building structure. Shadowing the structure of the building, the captured heat gain through windows and masonry parts will be reduced.

Building form and layout: building orientation and an optimal distribution of the interior spaces can prevent overheating. The rooms can be divided into zones inside buildings, in order to fend off the sources of internal heat gain and/or assignment heat gains where they can be useful, considering the different construction activities. For example, the creation of a plan of flat and horizontal surface will increase the effectiveness of the crossventilation through the plane. Identification of areas can take advantage of vertical temperature stratification (Figure 4).

The use of flap type openings on the back and in the upper position will contribute chimney effect due to the difference of pressure and air temperature.

Typically, building zones in the upper levels are warmer than the lower zones due to stratification; vertical zoning of spaces and activities uses this temperature stratification to accommodate zone uses according to their temperature requirements. Form factor (i.e. the ratio between volume and surface) also plays a major role in the building's energy and thermal profile. This ratio can be used to shape the building form to the specific local climate [6]. For example, more compact forms tend to preserve more heat than less compact forms because the ratio of the internal loads to envelope area is significant.

Thermal insulation-insulation of the building envelope decreases the amount of heat transferred by radiation through the walls [7]. Since roofs could be a bigger contribution to the internal heat load, the entire roof is considered as a single solar photovoltaic; therefore, there is a gap between the cover PV and the slab which greatly increases the isolation of the interior. 


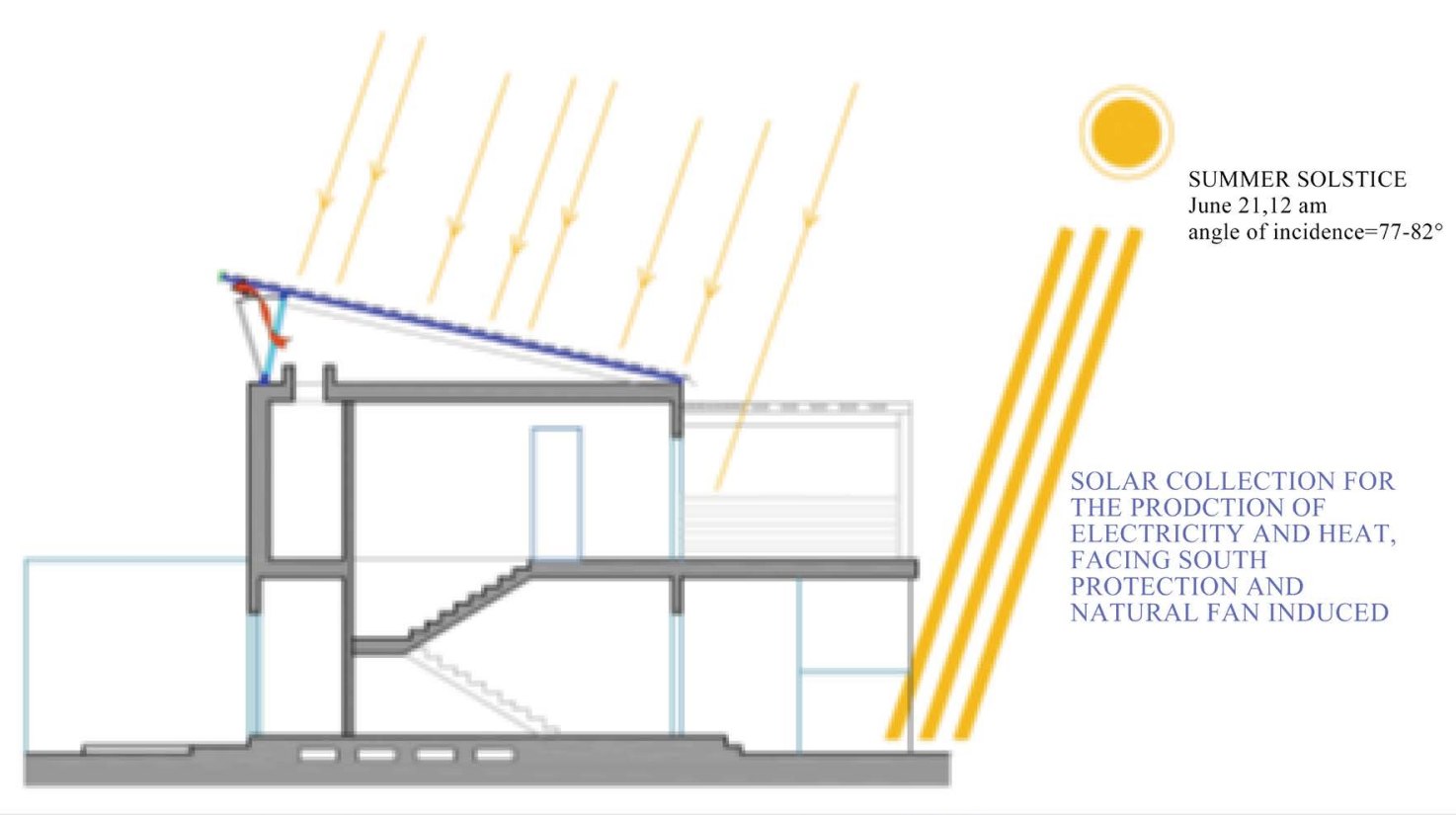

(a)

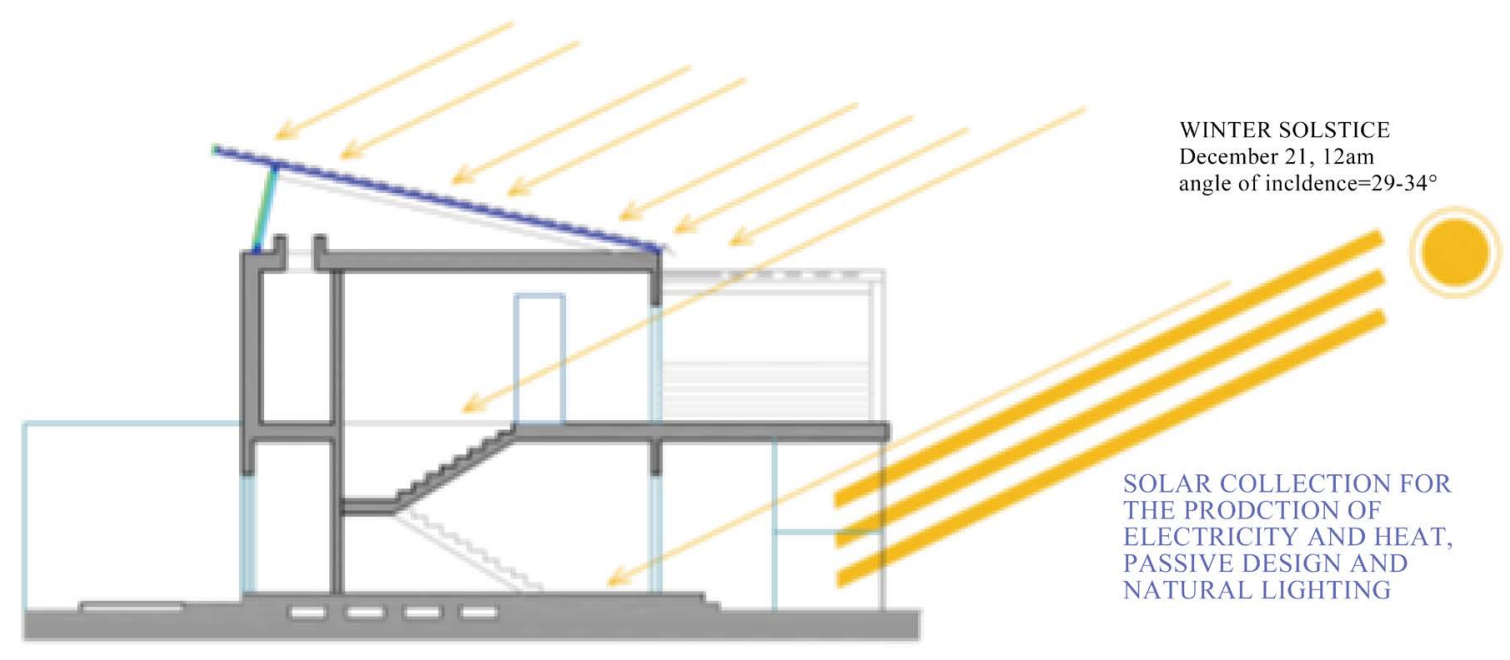

(b)

\section{Figure 4. (a) (b): Passive design application on resort.}

Behavioral and occupancy patterns-Some building management policies such as limiting the amount of people in a given area of the building can also contribute effectively to the minimization of heat gains inside a building. Building occupants can also contribute to indoor overheating prevention by: shutting off the lights and equipment of unoccupied spaces, operating shading when necessary to reduce solar heat gains through windows, or dress lighter in order to adapt better to the indoor environment by increasing their thermal comfort tolerance.

Internal gain control: More energy-efficient lighting and electronic equipment tend to release less energy thus contributing to less internal heat loads inside the space [8].

We proceed now to calculate what might be the energy contribution on the estimated demand for summer cooling of a system of pipelines placed below the building in question.

In other words, it provides for a network of ducts for the pre-cooling of the incoming air. The value of coverage of the requirements depend on the milker of the conduits, the diameter and the length over which the material that might help or not the heat exchange between air and ground [9] (Figure 5). 


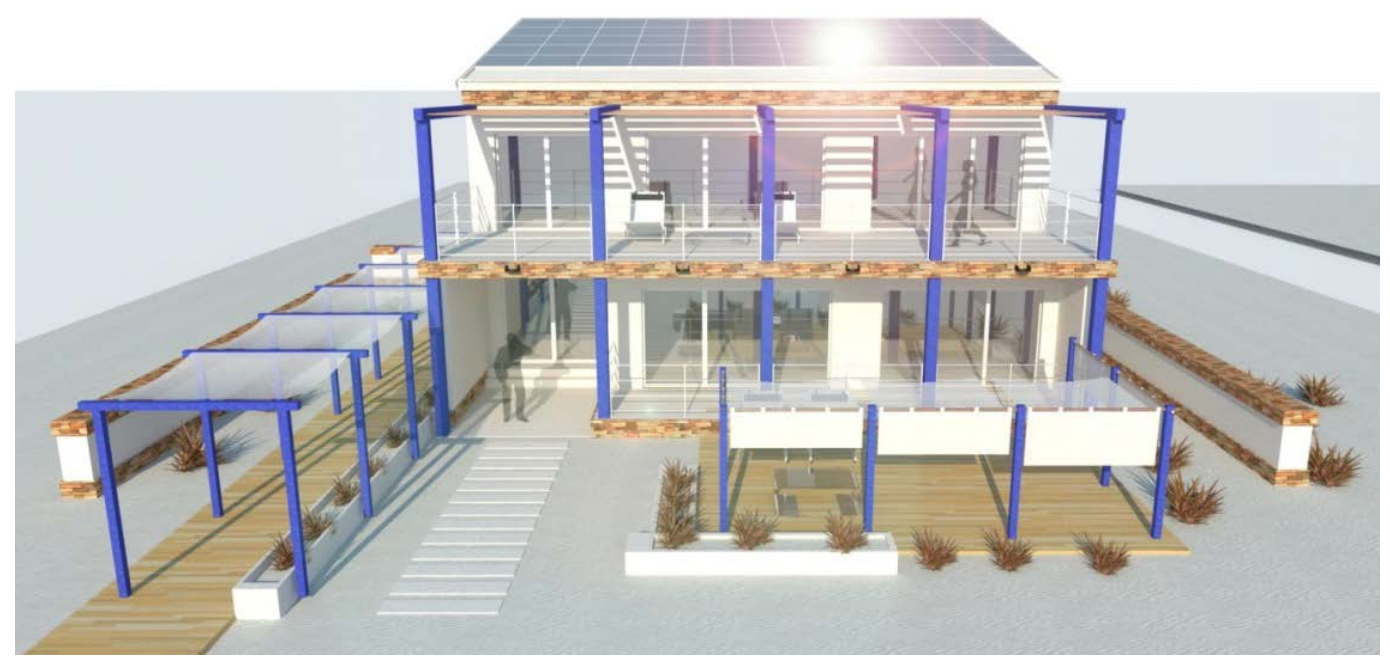

(a)

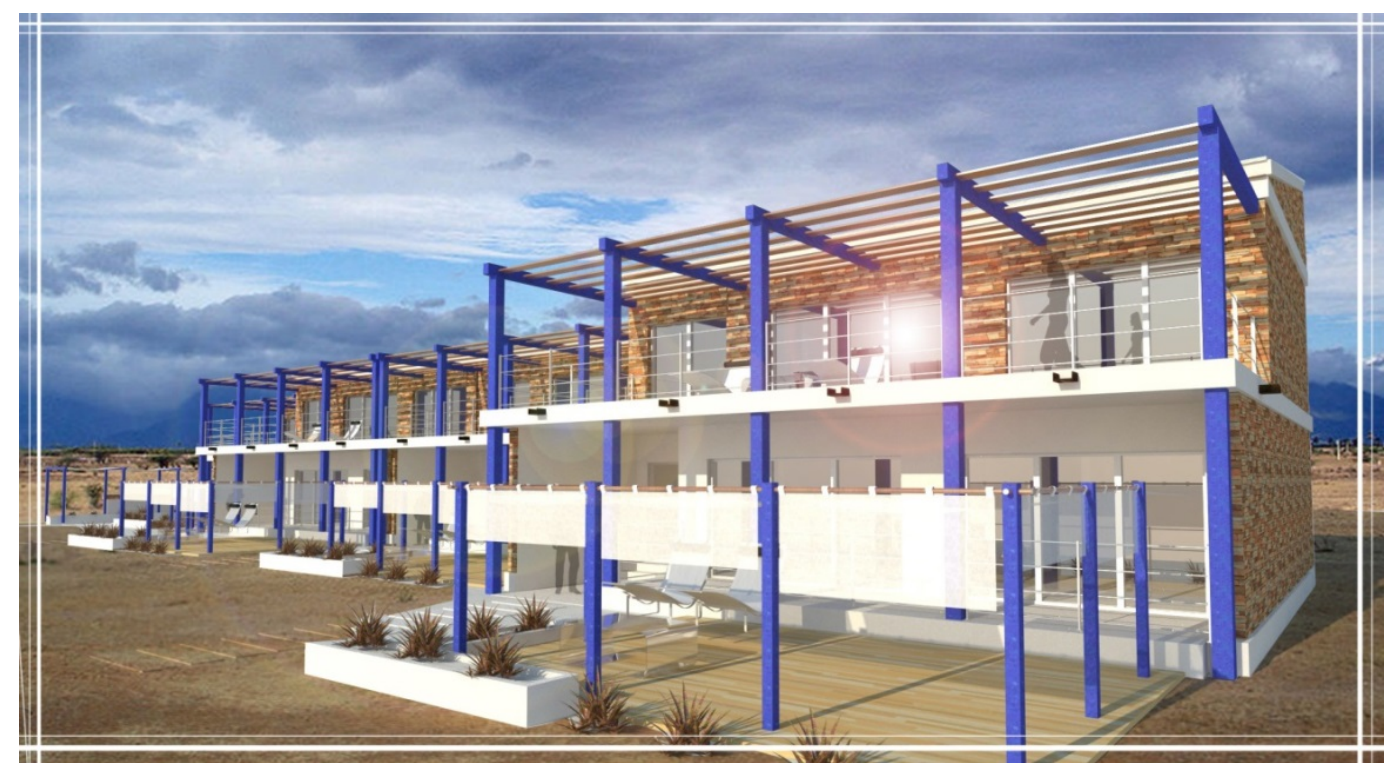

(b)

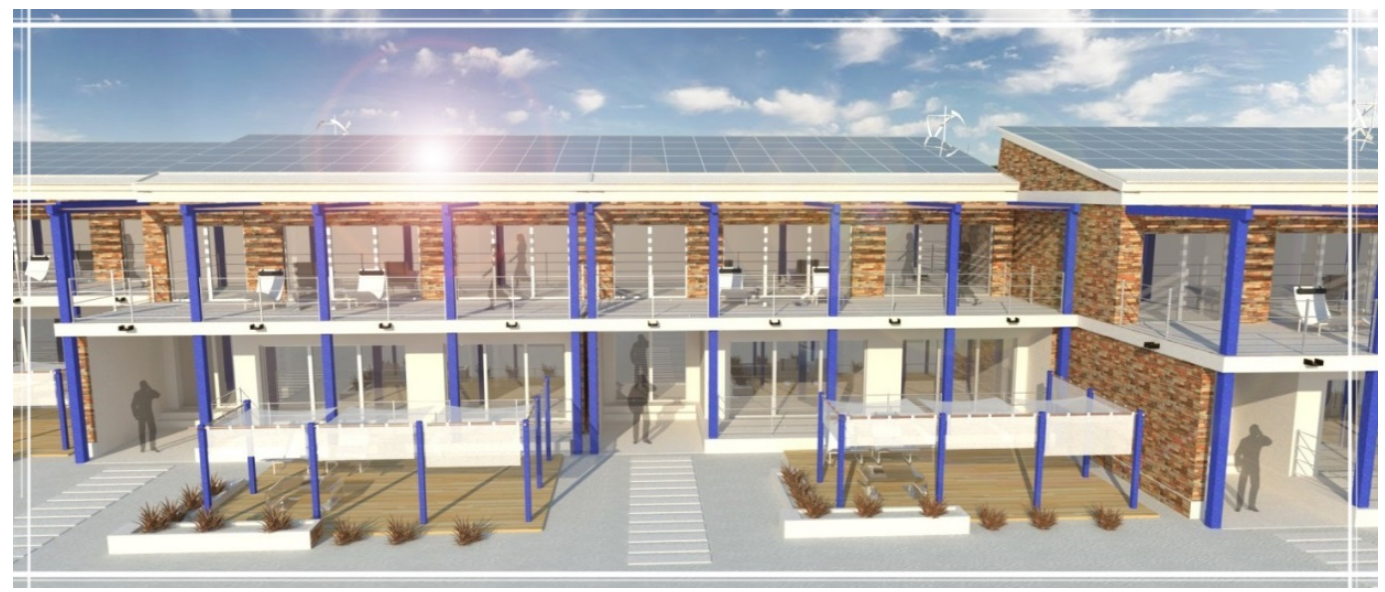

(c)

Figure 5. (a)-(c) Renderin. 


\section{Thermal and Cooling Devices}

For the calculation of energy performance and relationship building throughout the formation of the outer wall it is useful to know the main features [10] (Table 3).

Certainly the relative performance of thermal insulation in order to preserve the heat in the cold months is not predominant since the main requirement to the structure required is the function of thermal mass and especially of phase shift.

Summarizing is set out below the main calculations related to the energy of the building structure

$\begin{array}{ll}\text { Heating Demand } & 19.8 \mathrm{kWh} /\left(\mathrm{m}^{2} \mathrm{a}\right) \\ \text { Heating Load } & 28.0 \mathrm{~W} / \mathrm{m}^{2} \\ \text { Cooling Demand } & 6.6 \mathrm{kWh} /\left(\mathrm{m}^{2} \mathrm{a}\right) \\ \text { Cooling Load } & 60.0 \mathrm{~W} / \mathrm{m}^{2} \\ \text { Airtightness } & 0.61 / \mathrm{h} \\ \text { Primary Energy } & 15.0 \mathrm{kWh} /\left(\mathrm{m}^{2} \mathrm{a}\right)\end{array}$

The generation of heating and cooling uses is made using high-efficiency heat pumps with a coefficient of performance (COP) of 3.5/4. The building is then applied electrically and the system of internal parts of the exhausted air will benefit from a heat exchange with the ground below the building.

To increase the efficiency of the building envelope it is equipped with a heat exchanger with the ground consisting of standard tunnel located under the foundations, cast in concrete

The Fraction of thermal load covered by the system, calculated with Ashrae and Trnsys software, is about $38 \%$ while the cost of such geothermal system pre-heating or pre-cooling is negligible as it is exploited the thermal mass of the foundation of the building.

\section{Photovoltaics}

The roof of the building is able to accommodate a photovoltaic solar plant to an area of approximately 100 square meters.

Considering a useful technology for the hot and arid zones such as that of amorphous silicon or CIS, Which is synonymous with CIGS stands for the constituents copper $(\mathrm{Cu})$, indium (In), gallium $(\mathrm{Ga})$ and selenium $(\mathrm{Se})$ with an efficiency of $12 \%$ on standard test conditions (STC) of $1000 \mathrm{~W} / \mathrm{m}^{2}$, we are able to provide for a system of total power $8 \mathrm{kWp}$ [11] (Table 4, Table 5).

The production of electricity is much higher than the sum of the heat demand, cooling, domestic hot water production, mechanical ventilation and lighting devices (Figure 6, Figure 7).

\begin{tabular}{|c|c|}
\hline \multicolumn{2}{|l|}{ External Wall features } \\
\hline thick (s) & $41.5 \mathrm{~cm}$ \\
\hline Mass Superficial (m) & $531 \mathrm{~kg} / \mathrm{m}^{2}$ \\
\hline Thermal transmittance $(\mathrm{U})$ & $0.627 \mathrm{~W} / \mathrm{m}^{2} \mathrm{~K}$ \\
\hline Thermal resistance $(\mathrm{R})$ & $1595 \mathrm{~m}^{2} \mathrm{~K} / \mathrm{W}$ \\
\hline \multicolumn{2}{|l|}{ Thermal parameters Dynamic Form } \\
\hline Periodic thermal transmittance (Yie) & $0.106 \mathrm{~W} / \mathrm{m}^{2} \mathrm{~K}$ \\
\hline Heat capacity per unit area of internal $(\mathrm{Ki})$ & $48.9 \mathrm{~kJ} / \mathrm{m}^{2} \mathrm{~K}$ \\
\hline Heat capacity per unit area outside $(\mathrm{Ke})$ & $175.3 \mathrm{~kJ} / \mathrm{m}^{2} \mathrm{~K}$ \\
\hline Attenuation factor (f) & 0169 \\
\hline Phase shift $(\varphi)$ & $24.00 \mathrm{~h}$ \\
\hline Thermal admittance internal (Yii) & $3502 \mathrm{~W} / \mathrm{m}^{2} \mathrm{~K}$ \\
\hline Thermal admittance external (Yee) & $12,682 \mathrm{~W} / \mathrm{m}^{2} \mathrm{~K}$ \\
\hline Surface mass excluded plaster & $531 \mathrm{~kg} / \mathrm{m}^{2}$ \\
\hline
\end{tabular}


Table 4. PV sizing.

Solar sizing: irradiation conditions and the electrical output of the PV system

Estimates of solar PV electricity generation

Location: $36^{\circ} 26^{\prime} 5^{\prime \prime}$ North, $28^{\circ} 13^{\prime} 2^{\prime \prime}$ East, Elevation

Solar radiation database used

$56 \mathrm{~m}$ a.s.l.,

Nominal power of the PV system

PVGIS-CMSAF

$8.0 \mathrm{~kW}$ (CIS)

Estimated losses due to temperature and low irradiance

$9.6 \%$ (using local ambient temperature)

Estimated loss due to angular reflectance effects

$2.8 \%$

Other losses (cables, inverter etc.)

$14.0 \%$

Combined PV system losses

$4.4 \%$

Table 5. Average annual PV electricity production and global irradiation.

\begin{tabular}{|c|c|c|c|c|}
\hline \multicolumn{5}{|c|}{ Fixed system: inclination $=15^{\circ}$, orientation $=0^{\circ}$} \\
\hline Month & $\mathbf{E}_{\mathrm{d}}$ & $\mathbf{E}_{\mathbf{m}}$ & $\mathbf{H}_{\mathrm{d}}$ & $\mathbf{H}_{\mathrm{m}}$ \\
\hline Jan & 21.10 & 655 & 3.35 & 104 \\
\hline Feb & 25.80 & 723 & 4.12 & 115 \\
\hline Mar & 37.10 & 1150 & 6.01 & 186 \\
\hline Apr & 41.10 & 1230 & 6.72 & 202 \\
\hline May & 45.10 & 1400 & 7.53 & 234 \\
\hline Jun & 48.90 & 1470 & 8.27 & 248 \\
\hline Jul & 48.70 & 1510 & 8.30 & 257 \\
\hline Aug & 46.10 & 1430 & 7.86 & 244 \\
\hline Sep & 40.90 & 1230 & 6.89 & 207 \\
\hline Oct & 32.70 & 1010 & 5.42 & 168 \\
\hline Nov & 24.20 & 725 & 3.93 & 118 \\
\hline Dec & 18.60 & 577 & 2.97 & 92.2 \\
\hline Yearly average & 35.9 & 1090 & 5.96 & 181 \\
\hline Total for year & \multicolumn{2}{|c|}{13,200} & \multicolumn{2}{|c|}{2170} \\
\hline
\end{tabular}

$\mathbf{E}_{\mathrm{d}}$ : Average daily electricity production from the given system $(\mathrm{kWh}) ; \mathbf{E}_{\mathbf{m}}$ : Average monthly electricity production from the given system $(\mathrm{kWh}) ; \mathbf{H}_{\mathrm{d}}$ : Average daily sum of global irradiation per square meter received by the modules of the given system $\left(\mathrm{kWh} / \mathrm{m}^{2}\right) ; \mathbf{H}_{\mathrm{m}}$ : Average sum of global irradiation per square meter received by the modules of the given system $\left(\mathrm{kWh} / \mathrm{m}^{2}\right)$.

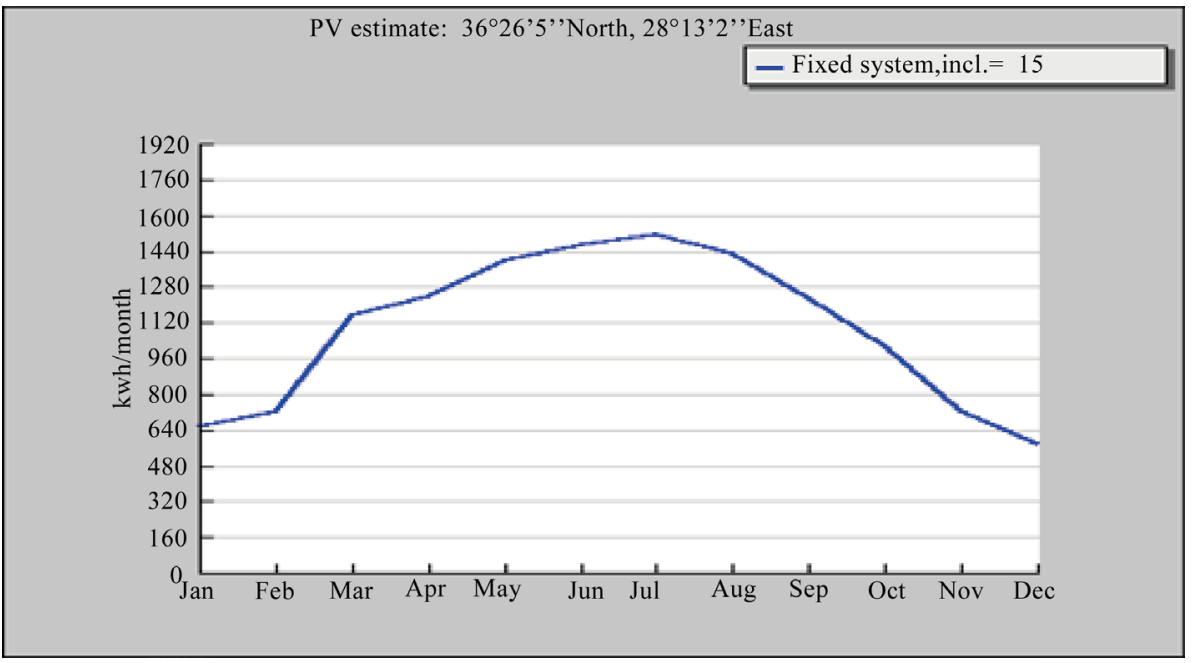

Figure 6. Diagram of PV production in $\mathrm{kWh} /$ mouth. 


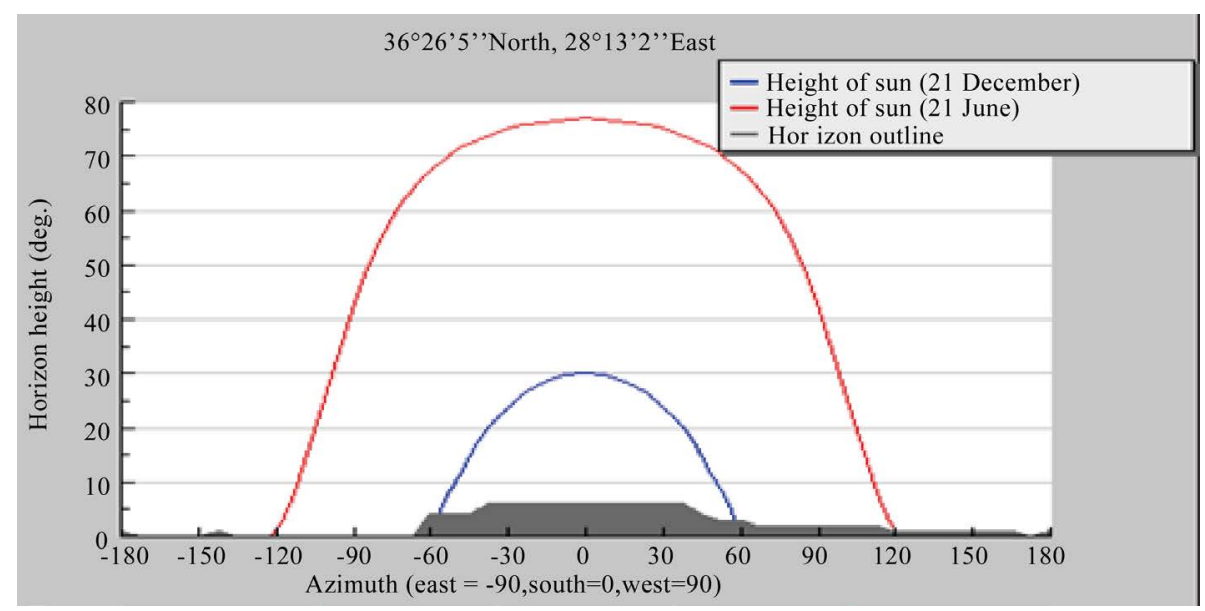

Figure 7. Diagram of sun height and horizon line.

The production of electrical energy is much higher than the overall requirements of the building.

Systems are then used for generating heat and cold as efficient heat pumps for the heating requirements, cooling, domestic hot water production, mechanical ventilation and lighting devices.

The entire energy consumption, thanks to the choices of materials, techniques and passive design of the building is covered by the energy production of the only solar photovoltaic system [12].

The energy production is much higher than the requirement but can occur at different times from the use. It is therefore necessary to provide the system-building of a storage facility capable of accumulating excess energy produced during daylight hours and make it available at night time [13].

Storage will consist of a charger for an energy of $6.4 \mathrm{kWh} /$ day; the useful energy to recharge daily will be provided by the photovoltaic system in about $1-2$ hours of production. As seen from the graph below there is a surplus of usable energy in a smart grid or usable for the production of hydrogen.

The chart above shows the energy balance of the building system. The surplus of electrical energy produced can be used to power a smart grid and to produce hydrogen through the electrolysis of water (Figure 8).

The hydrogen can then be stored and used for electric vehicles equipped with fuel cells.

The efficiency of the system is certainly less than the self-consumption but this way you can transform energy into a vector for a different use.

The efficiency of the system is certainly less than the self-consumption but this way you can transform energy into a vector for a different use.

In fact, when the storage is recharged energy would be fed into the grid while still making its inefficient production

\section{Hydrogen Production}

To calculate the amount of energy used to produce hydrogen is necessary to check the efficiency of the transformation.

As shown in the preceding diagrams, the split (yield $=70 \%$ ) of a liter of water in its components $\mathrm{H}_{2}$ and $\mathrm{O}_{2}$, for example, requires approximately $6.3 \mathrm{kWh}$ of electrical energy. The energy content of the hydrogen thus produced (approximately $1.3 \mathrm{~m}^{3}$ ) corresponds to approximately $4.41 \mathrm{kWh}$ of chemical energy (Figure 9).

If one obtains again electricity from $1.36 \mathrm{~m}^{3}$ of hydrogen with the use of a combined cycle or of a fuel cell it would be obtained approximately $2.2 \mathrm{kWh}$ of electrical energy.

The numbers given above might make it appear questionable and very inconvenient technology of electrolysis for hydrogen production. In fact, the above described process may be interesting in certain conditions. Consider the use of solar energy in the summer (low cost, abundance) in the climate of the Aegean and the exploitation of hydrogen stored for electric mobility. In this case, the analysis could be more favorable from the point of view of economic as well as ecological.

In fact even if the electrolysis is the most straightforward method for the production of pure hydrogen encounters major obstacles to the limited amount of product and for the costs are still too high, due to the use of 


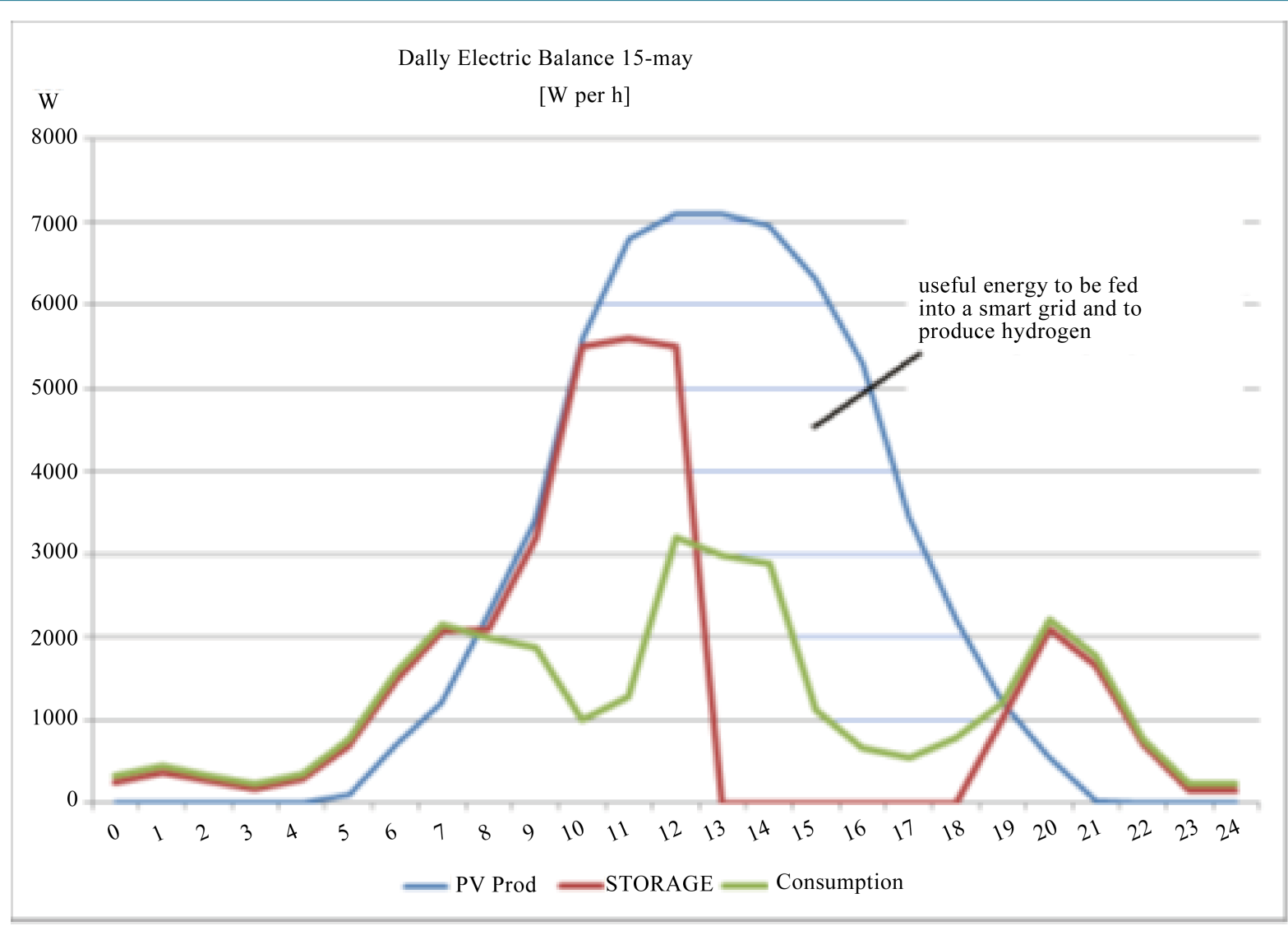

Figure 8. Daily electric Balance (Dynamic simulation at 15 May).

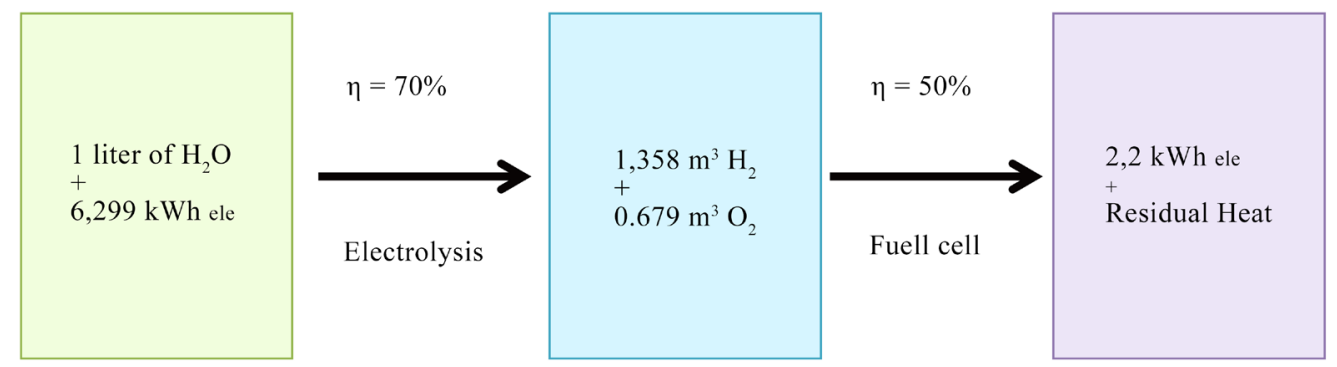

Figure 9. Process efficiency in hydrogen's production by electrolysis.

electrical energy. Currently, only 4\% of world production of hydrogen by electrolysis takes place [14].

In the present case, the availability of surplus energy and the possibility of storing hydrogen and its end-use for the mobility fuel cell make the production useful from the environmental point of view.

\section{Hydrogen Utilization: Fuel Cells}

The Fuel Cell Technologies should be a comprehensive portfolio of activities that address the full range of barriers facing the development and deployment of hydrogen and fuel cells with the ultimate goals of decreasing our dependence on oil, reducing carbon emissions, and enabling clean, reliable power generation.

One of the advantages of fuel cells is that hydrogen fuel can be derived using a variety of domestic resources such as biomass, water electrolysis, natural gas, propane, and methanol. Hydrogen generated by water electrolysis, which is the splitting of water molecules into hydrogen and oxygen using electricity, can be beneficial when used in combination with variable renewable energy technologies such as solar and wind. When the electricity 
used for water electrolysis is produced by a variable renewable energy source, the hydrogen stores the unused energy for later use and is classified as a renewable fuel and energy resource.

Fuel cells have been used for many years in the space program to provide electricity and drinking water for astronauts as well as industrial applications. The applications are classified into the following three categories: transportation, stationary power stations, and portable power. This overview focuses on stationary power station applications.

Benefits and advantages of fuel cell technologies include:

- Near zero emissions at the point of operation

- Reduction in current and future electricity costs through the efficient use of renewable energy technologies

- A high-quality, reliable, and consistent power supply as long as fuel is supplied

- Higher electrical efficiency than traditional combustion power supplies

- Combined heat and power installations of fuel cells, which further increases efficiency by utilizing the heat generated by the fuel cell for building heating needs

- Fuel-flexibility, enabling the use of a variety of domestic energy sources (e.g. hydrogen, natural gas, and methanol)

- Silent operation 24 hours per day, 7 days per week

- A wide range of applications to choose from.

This overview is intended to provide specific details for Federal Agencies considering fuel cells and renewable hydrogen as part of a construction project (Figure 10, Table 6).

It is possible to allocate $3500 \mathrm{kWh}$ per year for the production of about $555 \mathrm{~m}^{3}$ of hydrogen usable for mobility.

The energy balance [15] of the above graph clearly shows that the energy needs of a building with low consumption can be more than covered by a system of production such as solar PV and that the excess energy produced can be useful for producing hydrogen for use in mobility (Figure 11).

\section{Conclusions}

Low Mediterranean region is a hot spot for solar technology in general as conventional energy prices as well as solar radiation are very high. With the Bioclimatic techniques, mass and natural ventilation strategies and solar systems for electric, heating and cooling supply Zero Energy Building becomes highly innovative, replicable and really environmental project in this region [16].

\begin{tabular}{ccc|}
\hline Table 6. Global energy Balance. & & \\
\hline Energy Balance & Consumption/Production (kWh) & Percentual (\%) \\
\hline Space heating & 1200 & $4.49 \%$ \\
DHW & 3650 & $13.67 \%$ \\
Generation from Electric Photovoltaic Solar & $\mathbf{1 3 , 2 0 0}$ & $\mathbf{4 9 . 4 3 \%}$ \\
Contribution from geothermalventilation & $\mathbf{3 0 7}$ & $\mathbf{1 . 1 5 \%}$ \\
Conditioning/Dehumidifiers & 1200 & $4.49 \%$ \\
lighting & 1400 & $5.24 \%$ \\
cooking & 900 & $3.37 \%$ \\
appliances & 500 & $1.87 \%$ \\
Technicdevices & 600 & $2.25 \%$ \\
pumps & 120 & $0.45 \%$ \\
Production of hydrogen for Mobility & $\mathbf{3 5 0 0}$ & $\mathbf{1 3 . 1 1 \%}$ \\
Standby & 25 & $0.09 \%$ \\
Other & 100 & $0.37 \%$ \\
Total & $\mathbf{2 6 , 7 0 2}$ & $\mathbf{1 0 0 . 0 0 \%}$ \\
\hline
\end{tabular}




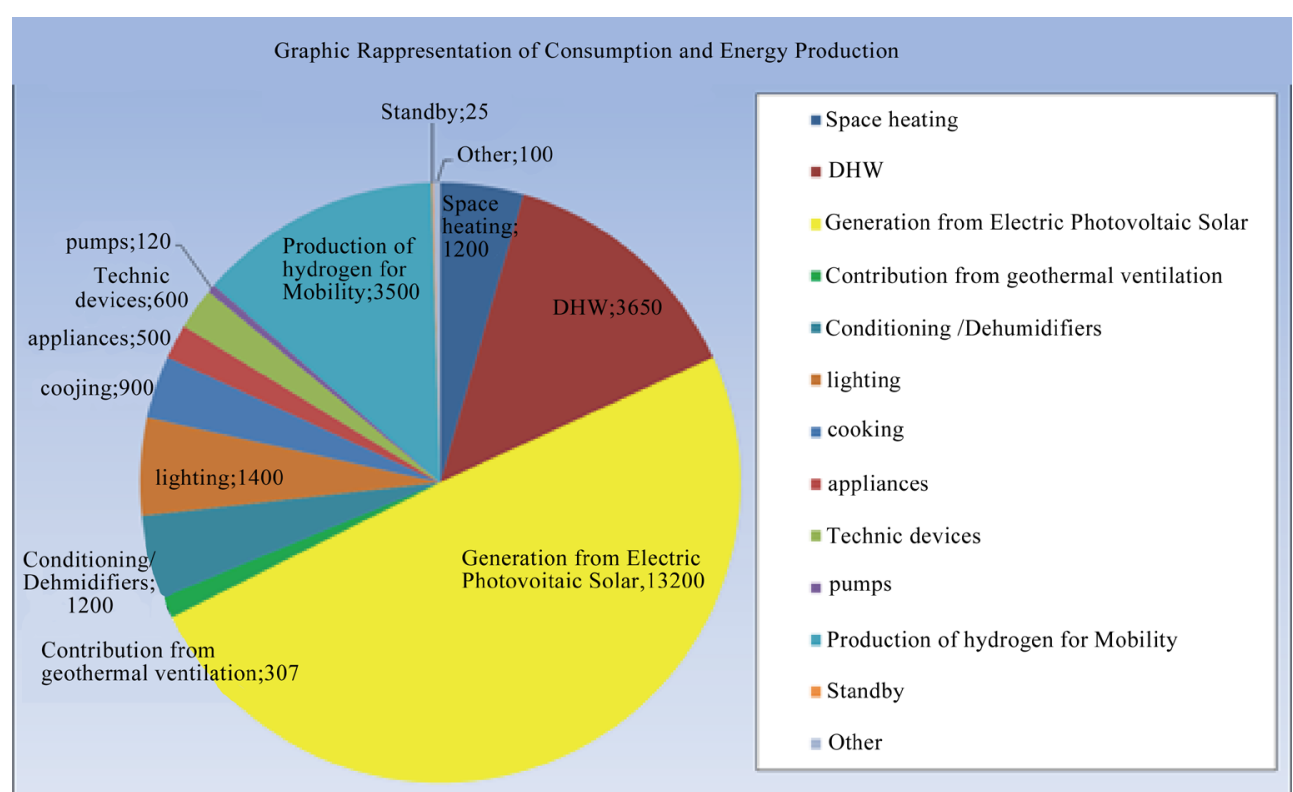

Figure 10. Annual energy Balance (kWh*year).

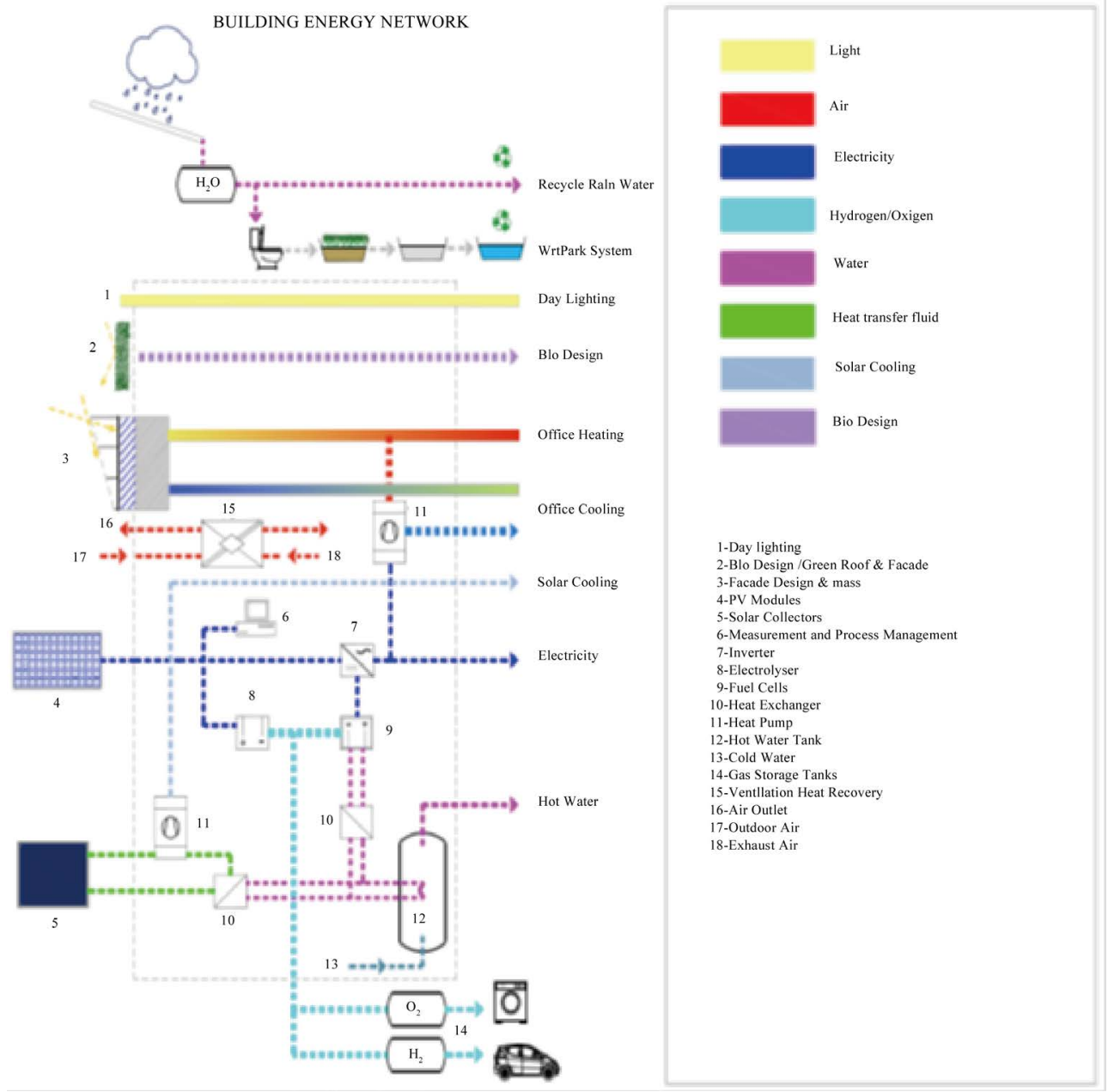

Figure 11. Final building energy Network. 
Energy balance demonstrates that exceed solar energy can be useful in hydrogen production for fuel cells vehicle use too.

Starting from a low energy building, the system is globally sustainable in terms of efficiency, use of resources, positive impact on other subsystems not only built environment.

The entire development will feature $8 \mathrm{~kW}$ of photovoltaic panels, which will generate about $36 \mathrm{kWh}$ of electricity each day, 13,200/y to supply high efficiency heating and cooling systems [17].

Some of the excess energy will be stored in a $6.4 \mathrm{kWh}$ lithium-ion battery banks, then, by applying an electrical current to water, electrolytes will be used to turn much of the rest of the excess power into hydrogen gas.

Through the computations of the annual energy balance [18] between building demand and supply energy, it is shown that the extra energy produced by the solar generation system is used also for the hydrogen sustainable mobility.

Key Points

Building annual consumption: $9700 \mathrm{kWh} / \mathrm{y}$

PV Annual Production: 13,200 kWh/y

Excess Energy: $3500 \mathrm{kWh} / \mathrm{y}$

$\mathrm{H}_{2}$ generation from excess energy: $555 \mathrm{~m}^{3} / \mathrm{y}$

\section{References}

[1] Lamacchia, F.P. and Perfetto, G. (2015) Sustainable and Competitive Hotels through Energy Innovation. Capital Matera Zero Energy Resort, Nearly Zero Energy Hotels 2015 Conference, Acropolis Nice (France), 24th June.

[2] Lamacchia, F.P. and Perfetto, G. (2015) Hydrogen for Energy and Sustainable Development (HFORE \& SD) (Il vettoreIdrogeno per l'Energia e lo SviluppoSostenibile)_European Energy Day by EU during Sustainable Energy Mounth of June 2015. EUSEW, Workshop on Energy Related-Issues Targeted to Professional Engineers, Architects and Technicians, (Workshop tematico per tecniciprofessionistiingegneri, architetti, geometri e periti), Held in Matera, Italy, 11th June2015.

[3] Lamacchia, F.P. and Perfetto, G. (2014) Nearly Zero Energy Buildings (nZEB)'s Design in South Europe- Mediterranean Climate, European Energy Day by EU during Sustainable Energy Week, 23-27th June 2014. EUSEW, Workshop on Energy Related-Issues Targeted to Professional Engineers, Architects and Technicians (Workshop tematico per tecniciprofessionistiingegneri, architetti, geometri e periti), Held in Matera, Italy, 27th June 2014.

[4] Tsoutsos, T., Tournaki, S., de Santos, C.A. and Vercellotti, R. (2013) Nearly Zero Energy Buildings Application in Mediterranean Hotels. Energy Procedia, 42, 230-238. http://dx.doi.org/10.1016/i.egypro.2013.11.023

[5] Farrou, I., Kolokotroni, M. and Santamouris, M. (2012) A Method for Energy Classification of Hotels: A Case-Study of Greece. Energy and Buildings, 55, 553-562. http://dx.doi.org/10.1016/j.enbuild.2012.08.010

[6] European Commission (2012) Commission Delegated Regulation (EU) No 244/2012 of 16 January 2012 Supplementing Directive 2010/31/EU on the Energy Performance of Buildings. Official Journal, L081.

[7] European Commission (2011) A Roadmap for Moving to a Competitive Low Carbon Economy in 2050. COM(2011) 112 final.

[8] IEA (2013) Energy Efficiency Requirements in Building Codes: Energy Efficiency Policies for New Buildings. Assessed January. http://www.iea.org/publications/freepublications/publication/Building Codes-1.pdf\%20

[9] Zografakis, N., Gillas, K., Pollaki, A., Profylienou, M., Bounialetou, F. and Tsagarakis, K. (2011) Assessment of Practices and Technologies of Energy Saving and Renewable Energy Sources in Hotels in Crete. Renewable Energy, 36, 1323-1328. http://dx.doi.org/10.1016/j.renene.2010.10.015

[10] European Commission (2010) Directive 2010/31/EU of 19 May 2010 on the Energy Performance of Buildings (Recast). Official Journal, L153/13.

[11] Perfetto, G. (2010) BIPV Building Integration Photovoltaics Systems: Technical \& Architectural Issues. The Master Builder n. 10.

[12] (2006) Sistemi Fotovoltaici e Termici-Strumenti per il Progettista"/“Photovoltaic and Solar Thermal Systems. Designer's Handbook, AAVV-CELID-Torino.

[13] (2003) I Sistemi Solari Fotovoltaici: Caratteristiche, Dimensionamento e Integrazione Architettonica/Photovoltaics Solar Systems: Requirements, Design and Building Integration: Lecture to the Laboratory of TechnologicalInnovation (F0T1). G. Perfetto - Politecnico di Torino, AA 2003-6.

[14] (2010) Hydrogen and Fuel Cells: Fundamentals, Technologies and Applications. Edited by Detlef Stolten, WILEY$\mathrm{VCH}$. 
[15] Karagiorgas, M., Tsoutsos, T. and Moiá-Pol, A. (2007) Analysis, Simulation and Monitoring of Energy Consumption in Mediterranean Hotels. Application in Greece. Energy and Buildings, 39, 416-426. http://dx.doi.org/10.1016/j.enbuild.2006.07.008

[16] Karagiorgas, M., Tsoutsos, T., Drosou, V., Pouffary, S., Pagano, S., Lara, G.L. and Mendes, J.M. (2006) HOTRES: Renewable Energies in the Hotels. An Extensive Technical Support for the Hotel Industry. Renewable and Sustainable Energy Reviews, 10, 198-224. http://dx.doi.org/10.1016/j.rser.2004.09.012

[17] Tsoutsos, T., Anagnostou, J., Pritchard, C., Karagiorgas, M. and Agoris, D. (2003) Solar Cooling Technologies in Greece. Applied Thermal Engineering, 23, 1427-1439. http://dx.doi.org/10.1016/S1359-4311(03)00089-9

[18] CRES (1998) A Strategy for Energy Efficiency and Use of RES in the Mediterranean Hotel Sector. STR 0489-95-GR Thermie Final Report, DG 17th. 